\title{
SEDENTARY CILIATES FROM TWO DUTCH FRESHWATER GAMMARUS SPECIES
}

\author{
by \\ M. J. BIERHOF \& P. J. ROOS \\ Zoological Laboratory, University of Amsterdam, The Netherlands
}

\begin{abstract}
The sedentary ciliate fauna living on the body surface of Gammarus tigrinus and $G$. pulex from Dutch freshwater habitats has been investigated. Fourty-seven ciliate species are found, of which 43 belong to the order Peritrichida, suborder Sessilina, 3 belong to the order Suctorida and 1 belongs to the order Chonotrichida. Two new species in the genera Intranstylum and Pseudocarchesium are described.

It appears that there is a seasonal variation in the number of epizoic ciliates as well as in species composition. In general, the species with a contractile stalk are found on external, often fast-moving, body parts. Species with a noncontractile stalk seem to prefer more quiet and sheltered positions. After ecdysis there is a succession of the genera Epistylis and Zoothamnium, the latter becoming dominant on older exoskeletons.
\end{abstract}

\section{INTRODUCTION}

From September 1972 to December 1973 the epifauna of Gammarus tigrinus Sexton, 1939, and G. pulex (Linnaeus, 1758) was investigated. At first this study was intended as a contribution to the regional fauna, as no research with special reference to these sedentary ciliates existed there, but secondarily the authors became interested in relations between the morphology of the ciliates and the site of attachment to the host.

Comparable work had been done earlier in other countries as West Germany, Hungary and Denmark (e.g. Biegel, 1954; Matthes, 1950; Nenniger, 1948; Sommer, 1951; Stiller, 1941; Fenchel, 1965). Especially the Germans, from the Erlangen school, stressed the symphoriont life habit and the host- and organ-specificity of the peritrichous ciliates.

Most of the ciliates we found, likewise belong to the Peritrichida, suborder Sessilina, some belong to the Suctorida and 1 species belongs to the Chonotrichida. The hosts belong to the Arthropoda, class Crustacea, order Amphipoda, family Gammaridae. These species were chosen because they are both easily captured in numbers throughout the year and they are also used in other ecological work in our faculty. As these animals offer a great number of possible attachment sites, careful dissection of the hosts took considerable time, with the result that only a relatively small number of hosts could be investigated. The list of sedentary ciliates from these Gammarus species is therefore susceptible of being extended in the future.

\section{MATERIAL AND METHODS}

The amphipod host material was collected in the provinces of North-Holland, Utrecht and Gelderland of The Netherlands. Two gammarid species were found: Gammarus pulex and G. tigrinus. The latter is dominant in the brackish water in the western part of the country, where this American immigrant replaced the indigenous $G$. pulex in the recent past. In each locality about 25 animals were caught, mainly from vegetation or stones alongside the bank, using a fine-mesh dip net.

The ciliates were studied alive using a differential interference contrast microscope, after decapitation and dissection of the host.

\section{DESCRIPTION OF THE LOCALITIES}

1. Hierden, the "Hierdense beek", a clear and shallow brook. The banks and in part also the bottom are covered with vegetation. The bottom is sandy with accumulations of coarse material like twigs and leaves.

2. Spaarnwoude. Shallow, muddy ditches in the pastures between Amsterdam and Haarlem.

3. Burgerbrug. Reedy pool, North of Alkmaar. 
4. Waterland. A number of ditches in the pastures, North of Amsterdam.

5. Naardermeer, lake with much vegetation and marsh-wood, Southeast of Amsterdam.

6. Several waters, South of Amsterdam, mostly broad, with stony banks and little vegetation (Diemen, Bullewijk, Kromme Mijdrecht) or with much water lilies and unstrengthened banks (Gein).

\section{RESULTS}

Systematic part

DESCRIPTION OF THE CILIATES, WITH REMARKS ON ATTACHMENT SITE

When the species or higher taxa are well described elsewhere, no description is given here.

\section{Order PERITRICHIDA Suborder SESSILINA}

The species recorded in this paper are all stalked, aloricate animals, as is, with the exception of the stalkless, aloricate Lagenophrys, the rule in symphoriont peritrichs.

\section{Family EPISTYLIDAE}

\section{Epistylis zschokkei (Keiser, 1921)}

(Fig. 1)

Epistylis zschokkei; Kahl, 1935: 729.

Material: Waterland, 30.XI.1972, on G. tigrinus; Diemen, 28.V.1972, on G. tigrinus.

Zooids $30 \times 45 \mu \mathrm{m}$.

Colonies of $4-6$ zooids.

Attachment: on the joints of the gnathopods.

\section{Epistylis thienemanni Sommer, 1951}

(Fig. 2)

Epistylis thienemanni Sommer, 1951: 372.

Material: Burgerbrug, 24.X.1972, on G. tigrinus.

Zooids $60 \times 100 \mu \mathrm{m}$.

Length of the stalk $45 \mu \mathrm{m}$.

Greatest breadth of the stalk $40 \mu \mathrm{m}$.

Colonies of (1) - 5 zooids.

Attachment: on all gills.
Epistylis gammari Precht, 1935

(Fig. 3)

Epistylis gammari; Stiller, 1971: 36.

Material: Naardermeer, 14.VI.1973, on G. tigrinus; Bullewijk, 19.VI.1973, on G. tigrinus.

Zooids $30 \times 45 \mu \mathrm{m}$.

Length of the stalk $70 \mu \mathrm{m}$.

Colonies of about 5 zooids.

Attachment: on the first antenna.

\section{Epistylis sp.}

(Fig. 4)

Material: Waterland, 12.I.1973, on G. tigrinus.

The zooids are of a slim vase-like shape. The discus is wrinkled. The contractile vacuole is situated somewhat above the middle of the zooid. The vestibulum continues to the half of the length of the zooid. The macronucleus is sausageshaped, a little bent and lying horizontally in the middle of the zooid. There are some small food vacuoles. The pellicle has a coarse transverse striation. Directly below the scopula, the stalk is straight for about $10 \mu \mathrm{m}$ and clearly striped. Further down, the stalk is enveloped in a slimy, wrinkled sheath.

Zooids $30 \times 60 \mu \mathrm{m}$.

Length of the colony $250 \mu \mathrm{m}$.

Three colonies of 9,6 and 2 zooids.

Attachment: on the first antenna, between the setae.

Epistylis nitocrae Precht, 1935

(Fig. 5)

Epistylis nitocrae Precht, 1935: 438.

Material: Naardermeer, 19.I.1973, on G. tigrinus.

Zooids $35 \times 65 \mu \mathrm{m}$.

Two colonies of 25 and 60 zooids.

Attachment: on the third pereiopod.

Epistylis ovalis Biegel, 1954

(Fig. 6)

Epistylis ovalis Biegel, 1954: 161.

Material: Diemen, 28.V.1973, on G. tigrinus; Gein, 23.VII.1973, on G. tigrinus. 

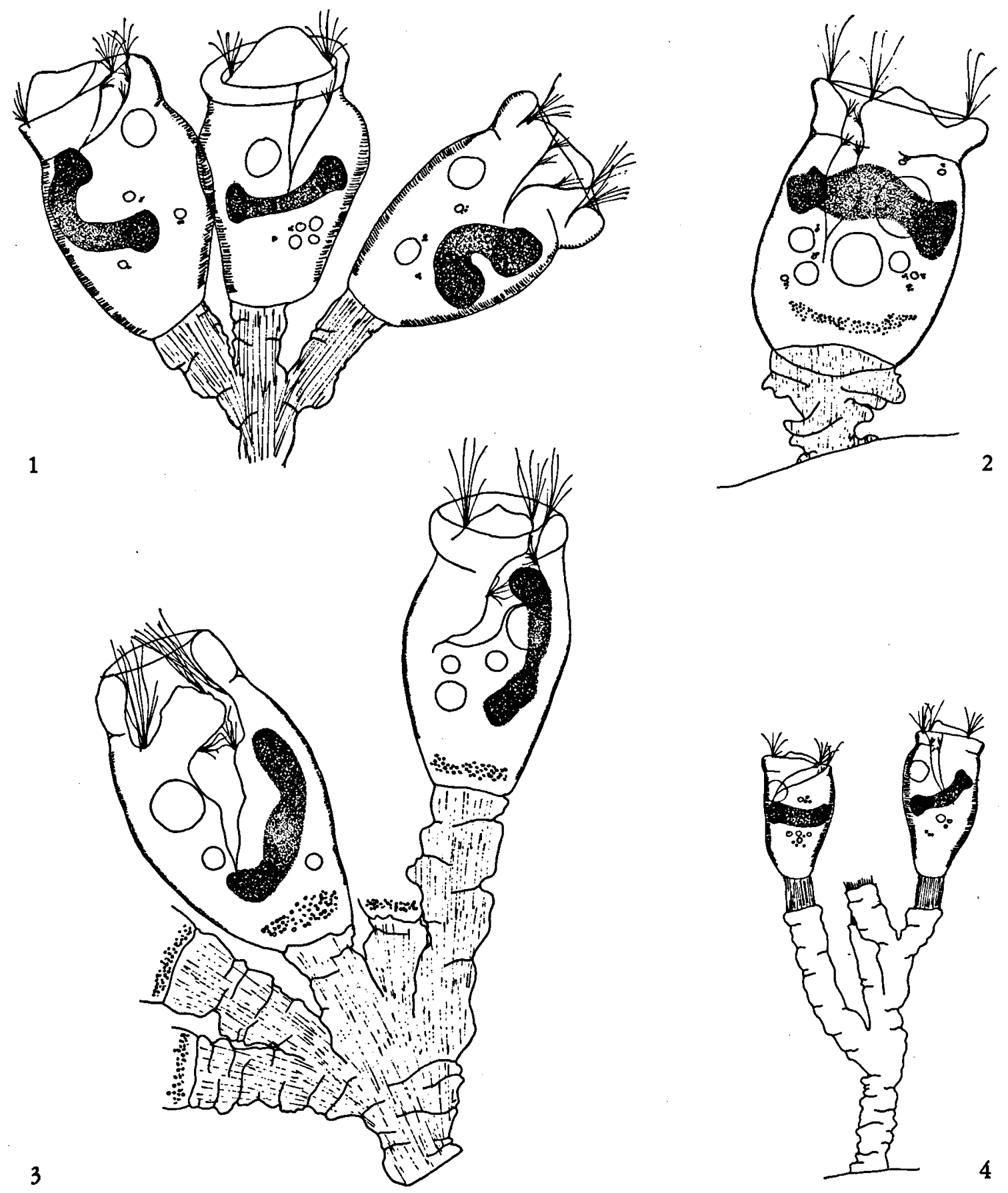

Fig. 1. Epistylis zschokkei (Keiser, 1921).

Fig. 2. Epistylis thienemanni Sommer, 1951.

Fig. 3. Epistylis gammari Precht, 1935.

Fig. 4. Epistylis sp.

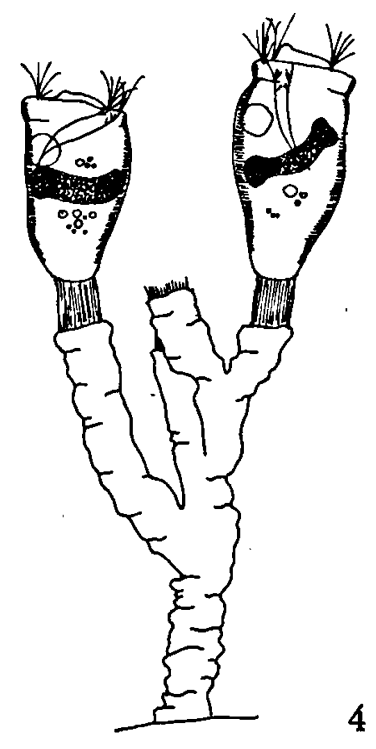



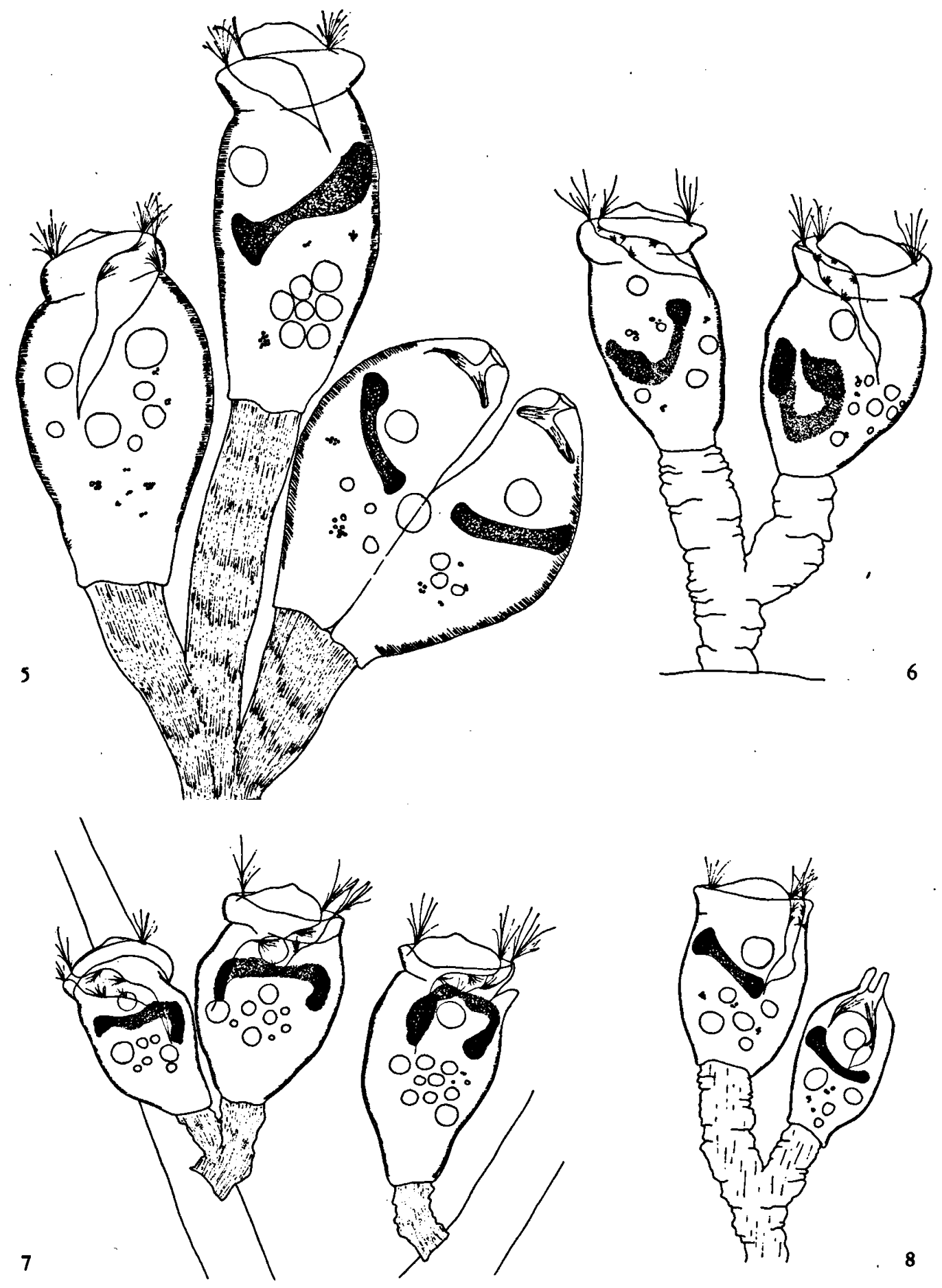

Fig. 5. Epistylis nitocrae Precht, 1935.

Fig. 6. Epistylis ovalis $\bar{B}$ iegel, 1954.

Fig. 7. Epistylis cf. ovalis Biegel, 1954.

Fig. 8. Epistylis cf. ovum (Kent, 1881). 
Zooids $30 \times 50 \mu \mathrm{m}$.

Colonies of two or three zooids.

Attachment: on the gnathopods.

Epistylis cf. ovalis Biegel, 1954

(Fig. 7)

Epistylis ovalis Biegel, 1954: 161.

Material: Gein, 14.VI.1973, on G. pulex.

The zooid resembles very much that of the above-mentioned $E$. ovalis. However, the macronucleus is situated in the upper part of the zooid and the stalk is striped lengthwise.

Zooids $25 \times 45 \mu \mathrm{m}$.

Stalk $10 \times 15 \mu \mathrm{m}$.

Attachment: on the third pereiopod.

Epistylis cf. ovum (Kent, 1881)

(Fig. 8)

Epistylis ovum; Stiller, 1941: 354.

Material: Naardermeer, 19.I.1973, on G. tigrinus.

The zooid is vase-like. The discus is convex. The peristome contracts snout-like. The contractile vacuole lies somewhat above the middle of the zooid. The narrow vestibulum continues to about half the length of the zooid. The nucleus is slightly bent, lying horizontally in the centre. There are some scattered food vacuoles. The stalk is thick, wrinkled, with a vague lengthwise striation.

Zooids $20 \times 40 \mu \mathrm{m}$.

One colony of 8 zooids.

Attachment: between the spines of the tip of the third uropod.

\section{Epistylis salina Stiller, 1941}

(Fig. 9)

Epistylis salina Stiller, 1941: 385.

Material: Hierden, 6.VIII.1973, on G. pulex.

Zooids $25 \times 55 \mu \mathrm{m}$.

Stalk $10 \times 50 \mu \mathrm{m}$.

Many small colonies of $2-9$ zooids.

Attachment: on first and second antennae, coxal plates and gills.

\section{Rhabdostyla sp.}

(Fig. 10)

Material: Gein, 23.VII.1973, on G. tigrinus.
The zooid is broad, nearly rectangular. The peristome is rather thick, not clearly separated. The discus is slightly wrinkled. The contractile vacuole is situated near the rim of the peristome. The rather narrow vestibulum continues into the lower half of the zooid. The ribbon-like macronucleus is slightly bent, situated in the underpart of the zooid. There are few food vacuoles. The pellicle has a very fine transverse striation.

Zooids $15 \times 25 \mu \mathrm{m}$.

Stalk $10 \times 40 \mu \mathrm{m}$.

Three animals.

Attachment: between the spines at the tip of the telson.

\section{Family VORTICELLIDAE}

Carchesium gammari Precht, 1935

(Fig. 11)

Carchesium gammari Precht, 1935: 442.

Material: Hierden, 26.IV.1973, on G. pulex.

Zooids $40 \times 70 \mu \mathrm{m}$.

Five colonies of 2, 3, 4 and 5 zooids.

Attachment: on the rims of the gills.

Carchesium duplicatum Precht, 1935

(Fig. 12)

Carchesium duplicatum Precht, 1935: 441.

Material: Hierden, 22.II.1973, 15.V.1973 and 6.VIII.1973, on G. pulex.

Zooids $30 \times 50 \mu \mathrm{m}$.

Length of the colony $150 \mu \mathrm{m}$.

Colonies up to about 50 zooids.

Attachment: on the rims of the gills of the pereiopods.

Carchesium jaerae Precht, 1935

(Fig. 13)

Carchesium jaerae Precht, 1935: 442.

Material: Gein, 23.VII.1973, on G. tigrinus.

Zooids $35 \times 55 \mu \mathrm{m}$.

Nine colonies of 2, 3 and 5 zooids.

Attachment: on the rims of the gills. 


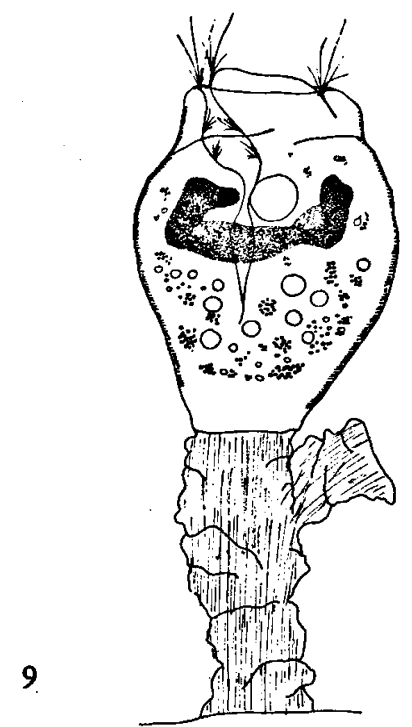

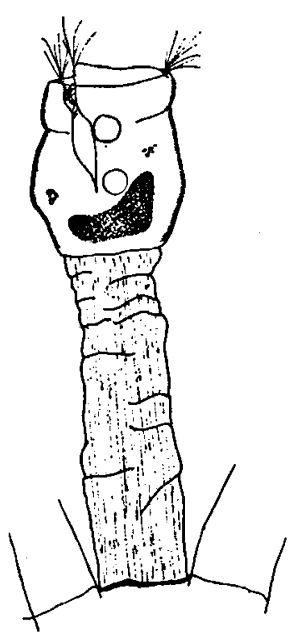

10

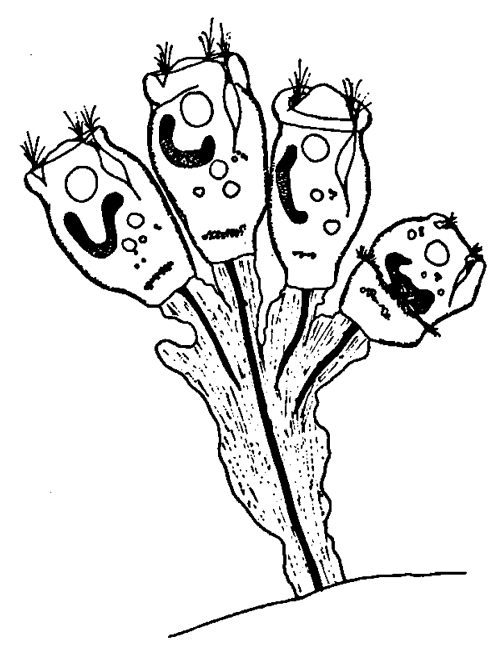

11
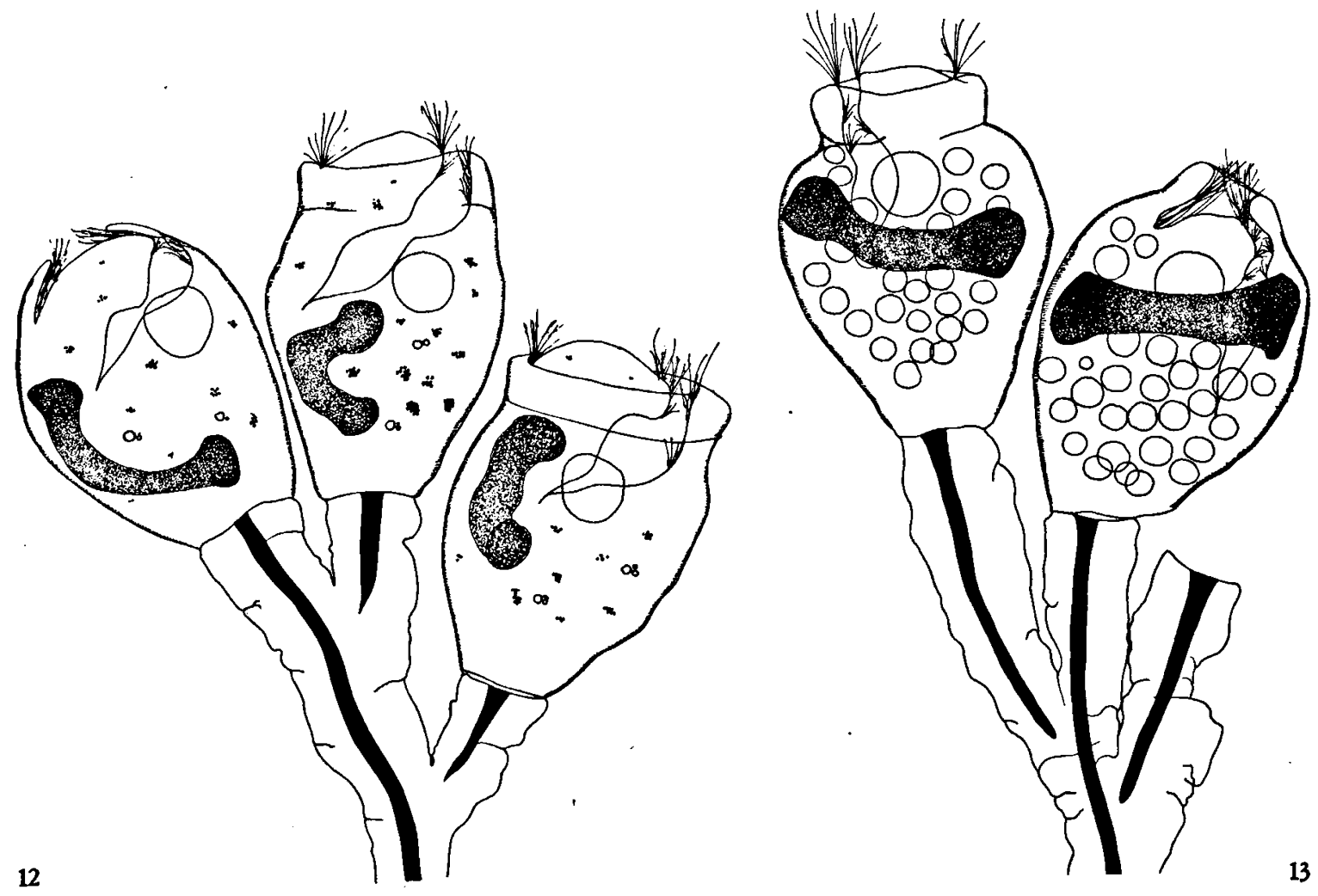

Fig. 9. Epistylis salina Stiller, 1941.

Fig. 10. Rhabdostyla sp.

Fig. 11. Carchesium gammari Precht, 1935.

Fig. 12. Carchesium duplicatum Precht, 1935.

Fig. 13. Carchesium jaerae Precht, 1935. 

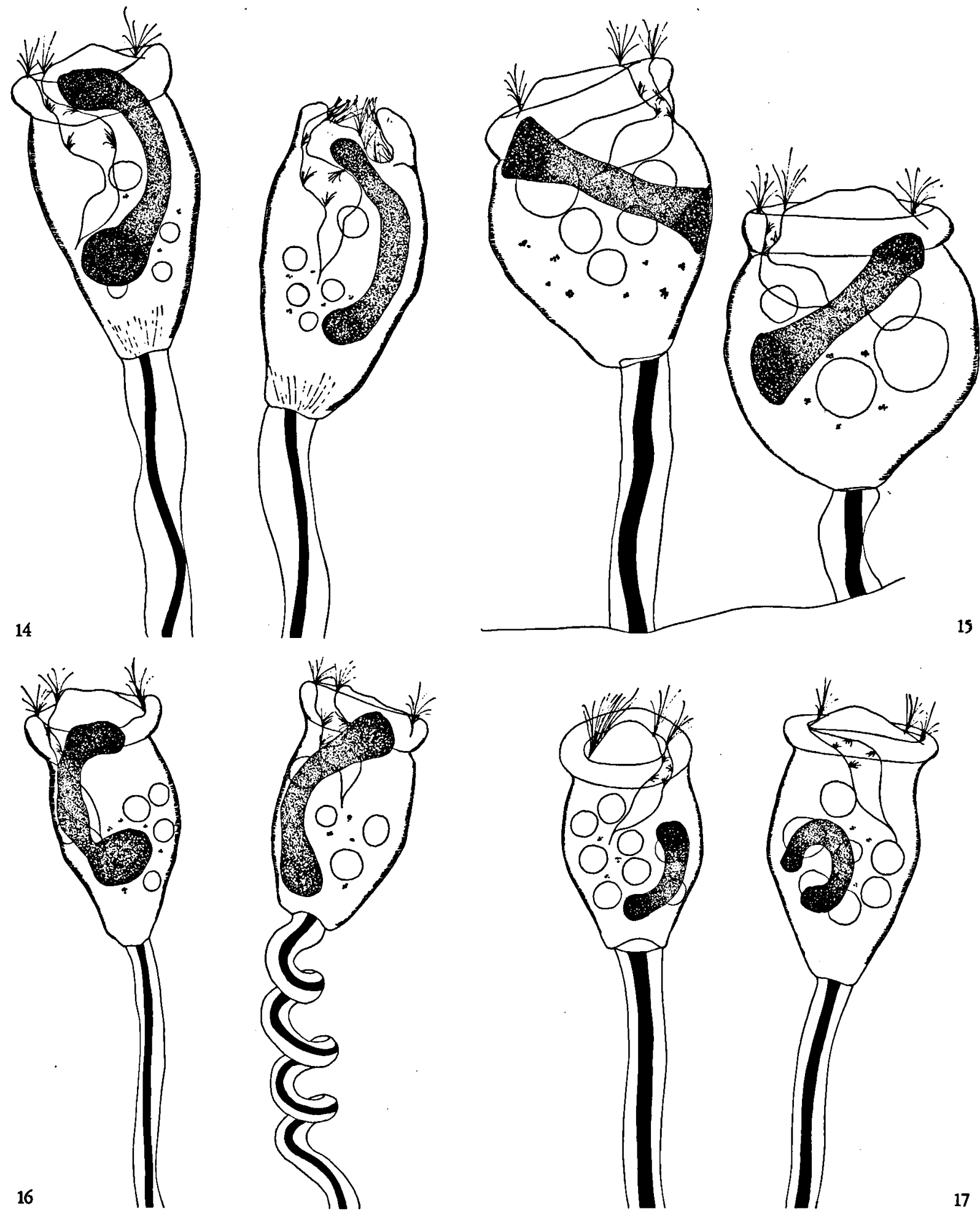

Fig. 14. Vorticella longifilum Kent, 1881.

Fig. 15. Vorticella microstoma Ehrenberg, 1830.

Fig. 16. Vorticella aequilata Kahl, 1935.

Fig. 17. Vorticella octava Stokes, 1885. 
Vorticella longifilum Kent, 1881

(Fig. 14)

Vorticella longifilum; Kahl, 1935: 719.

Material: Naardermeer, 15.III.1973, 20.III.1973, 18.IV.1973 and 15.VI.1973, on G. tigrinus.

Zooids $30 \times 65 \mu \mathrm{m}$.

Length of the stalk $250 \mu \mathrm{m}$.

Attachment: between the spines on the telson.

\section{Vorticella microstoma Ehrenberg, 1830}

(Fig. 15)

Vorticella microstoma; Kahl, 1935: 729.

Material: Naardermeer, 20.III.1973, on G. tigrinus.

Zooids $45 \times 65 \mu \mathrm{m}$.

Length of the stalk $40-80 \mu \mathrm{m}$.

Four animals.

Attachment: between coxal plate and leg.

\section{Vorticella aequilata Kahl, 1935}

(Fig. 16)

Vorticella aequilata Kahl, 1935: 725.

Material: Waterland, 30.III.1973, on G. tigrinus.

Zooids $25 \times 45 \mu \mathrm{m}$.

Length of the stalk $250 \mu \mathrm{m}$.

Eleven animals.

Attachment: between the spines on the telson.

\section{Vorticella octava Stokes, 1885}

(Fig. 17)

Vorticella octava; Stiller, 1971: 141.

Material: Naardermeer, 10.IV.1973, on G. tigrinus.

Zooids $35 \times 50 \mu \mathrm{m}$.

Length of the stalk $150 \mu \mathrm{m}$.

Six animals.

Attachment: between the spines on the telson.

Vorticella rotunda Nenniger, 1948

(Fig. 18)

Vorticella rotunda; Stiller, 1971: 147.

Material: Naardermeer, 18.IV.1973, on G. tigrinus.

Zooids $30 \times 50 \mu \mathrm{m}$.

Length of the stalk $80 \mu \mathrm{m}$.

Attachment: on a pereiopod.
Vorticella campanula Ehrenberg, 1831

(Fig. 19)

Vorticella campanula; Stiller, 1941: 414.

Material: Hierden, 6.VIII.1973, on G. pulex.

Zooids $40 \times 55 \mu \mathrm{m}$.

Stalk $20 \times 120 \mu \mathrm{m}$.

Many animals.

Attachment: on the pereiopods.

Vorticella convallaria (Linnaeus, 1758)

(Fig. 20)

Vorticella convallaria; Stiller, 1971: 133.

Material: Kromme Mijdrecht, 12.XII.1973, on G. tigrinus.

Zooids $(30-60) \times(50-80) \mu \mathrm{m}$.

Length of the stalk $300 \mu \mathrm{m}$.

In groups of 7 or 8 animals.

Attachment: on back and mouthparts.

Family ZOOTHAMNIDAE

Haplocaulus distinguendis Sommer, 1951

(Fig. 21)

Haplocaulus distinguendis; Stiller, 1971: 162.

Material: Spaarnwoude, 16.X.1972, on G. tigrinus; Hierden, 15.V.1973, on G. pulex; Waterland, 17.V.1973, on G. tigrinus; Gein, 23.VII.1973, on G. tigrinus.

Zooids $35 \times 70 \mu \mathrm{m}$.

In groups of 7 to 10 animals.

Attachment: on all pereiopods and gills.

Haplocaulus kahlii (Stiller, 1931)

(Fig. 22)

Haplocaulus kahlii; Sommer, 1951: 361.

Material: Diemen, 28.V.1973, on G. tigrinus.

Zooids $25 \times 40 \mu \mathrm{m}$.

Stalk short and wrinkled.

Three animals.

Attachment: on the rim of a gill.

\section{? Haplocaulus sp.}

(Fig. 23)

Material: Hierden, 6.VIII. 1973, on G. pulex.

The zooid is oblong, narrowed near the stalk. The peristome is rather thick. The discus is slightly wrinkled. The contractile vacuole is 

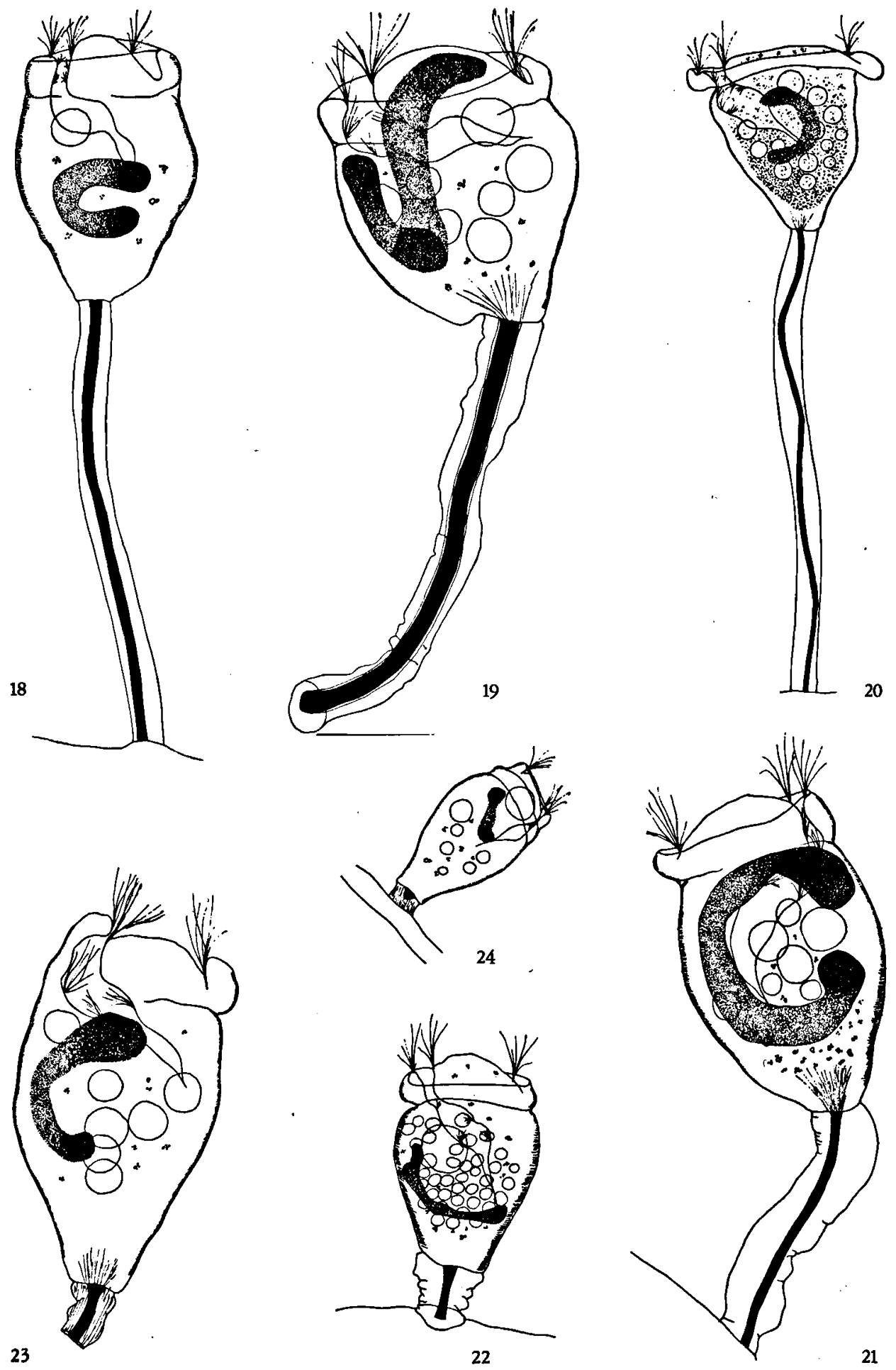

Fig. 18. Vorticella rotunda Nenniger, 1948.

Fig. 19. Vorticella campanula Ehrenberg, 1831.

Fig. 20. Vorticella convallaria (Linnaeus, 1758).

Fig. 21. Haplocaulus distinguendis Sommer, 1951.

Fig. 22. Haplocaulus kahlii (Stiller, 1931).

Fig. 23. ?Haplocaulus sp.

Fig. 24. Intranstylum variabilis Stiller, 1935. 
situated below the rim of the peristome. The vestibulum is widened in the middle and continues nearly horizontally to one third of the length of the zooid. Some large food vacuoles are present. The pellicle shows a fine transverse striation. At contraction the underpart of the zooid plies over the very short stalk. Therefore the way of contraction is undiscernible, and genus determination not possible.

Zooids $45 \times 75 \mu \mathrm{m}$.

Stalk $8 \times 10 \mu \mathrm{m}$.

One animal.

Attachment: on the first pereiopod.

Intranstylum variabilis Stiller, 1935

(Fig. 24)

Intranstylum variabilis; Stiller, 1971: 171.

Material: Spaarnwoude, 16.X.1973, on G. tigrinus.

Zooids $45 \times 85 \mu \mathrm{m}$.

Some colonies of 2 and 3 zooids.

Attachment: on coxal plates.

Intranstylum elegans Nenniger, 1948

(Fig. 25)

Intranstylum (Vorticella) elegans Nenniger, 1948: 210.

Material: Waterland, 12.I.1973, on G. tigrinus.

Zooids $50 \times 85 \mu \mathrm{m}$.

Length of the stalk $80 \mu \mathrm{m}$.

One solitary and one colony of 3 zooids.

Attachment: on the pereiopods.

Intranstylum barendrechti $n$. sp.

(Fig. 26)

Material: Gein, 14.VI.1973, on G. tigrinus.

The zooid is bell-shaped. The sausage-shaped peristome is broad and somewhat overhanging. The contractile vacuole is situated slightly above the middle of the zooid. The vestibulum opens widely and continues to nearly the full length of the zooid. Some large food vacuoles are present. The pellicle has a coarse transverse striation. The stalk is relatively long, the myoneme very short.

This species is a typical representative of its genus, as described by Nenniger (1948), but differs greatly from the other species in the stalk, which is far longer than those of the other species, and in the strikingly short myoneme.
The present species is dedicated to our director and colleague Prof. Dr. G. Barendrecht.

Zooids $50 \times 80 \mu \mathrm{m}$.

Length of the stalk $250 \mu \mathrm{m}$.

Length of the myoneme $40 \mu \mathrm{m}$.

Three solitaries and one colony of 4 zooids.

Attachment: on the back in front of the telson.

Pseudocarchesium amstelodamensis $\mathrm{n}$. sp.

(Figs. 27, 28)

Material: Waterland, 7.III.1973 and 30.III.1973, on G. tigrinus.

The zooid is vase-shaped and somewhat constricted near the peristome. The latter is thick and sausage-shaped. The umbilicate discus is wrinkled. The contractile vacuole is situated near the rim of the peristome. The vestibulum is widened in the middle. The macronucleus is $\mathrm{C}$ shaped and situated in the centre of the zooid. Some scattered food vacuoles and refractive granules are present at the bottom of the zooid. The pellicle shows a coarse transverse striation. The stalk is thick and wrinkled, with a lengthwise striation. The stalk myoneme of the side branches is connected with the elastic fibres of the main stem.

This species resembles $P$. ovatum Sommer, 1951 , but differs from the latter in the wrinkled discus and the very deep vestibulum.

The present species is dedicated to our University's city, at its 700th anniversary in 1975.

Zooids $35 \times 50 \mu \mathrm{m}$.

Stalk $15 \times 70 \mu \mathrm{m}$.

Colonies of $3-5$ zooids.

Attachment: on the gills of the pereiopods.

Zoothamnium parasiticum Stein, 1859

(Fig. 29)

Zoothamnium parasiticum; Stiller, 1971: 185.

Material: Waterland, 14.XI.1972, on G. tigrinus.

Zooids $35 \times 50 \mu \mathrm{m}$.

Three colonies of 2,3 and 7 zooids.

Attachment: at the junction of gill and gnathopod.

Zoothamnium varians Stiller, 1933

(Fig. 30)

Zoothamnium varians; Stiller, 1971: 179. 

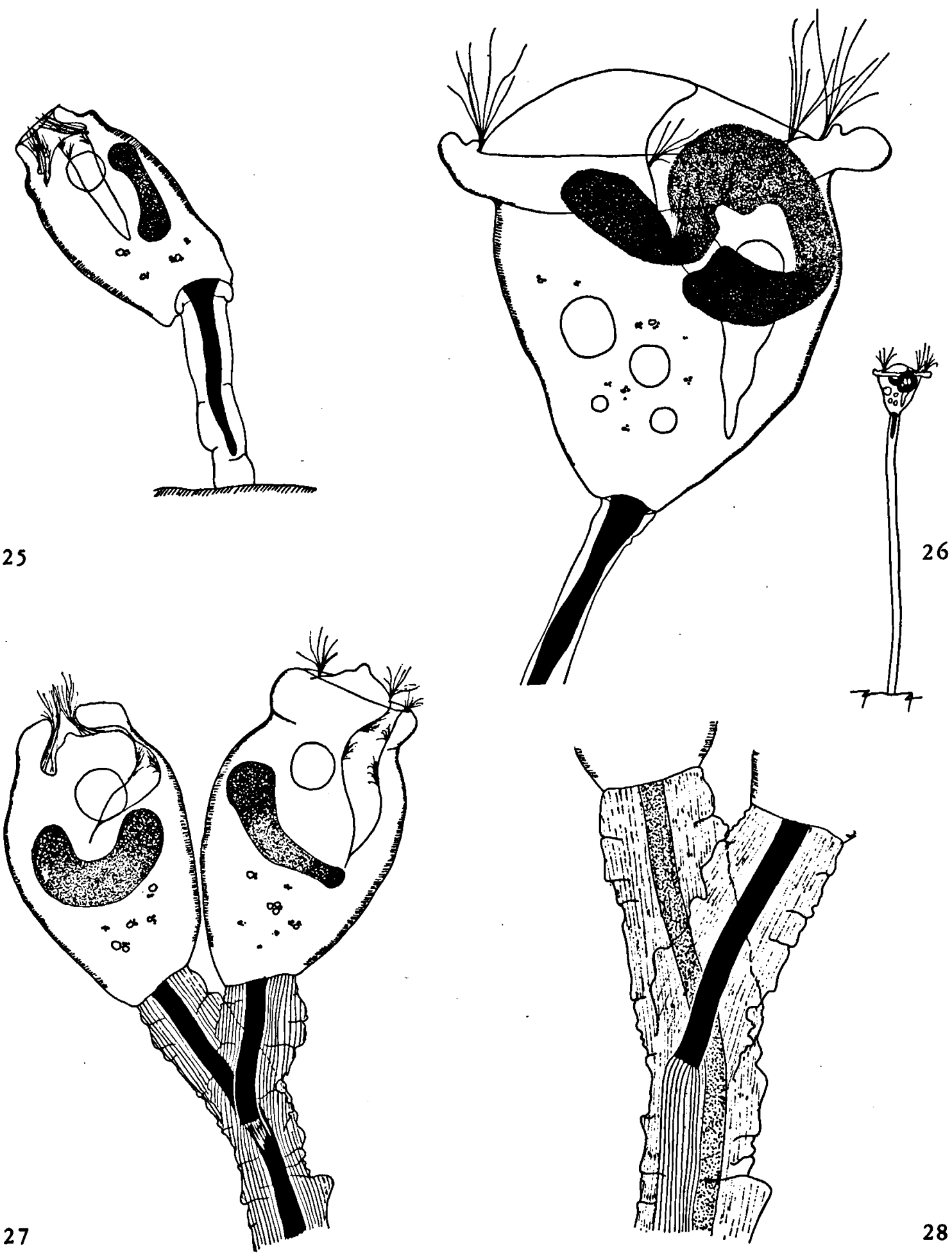

Fig. 25. Intranstylum elegans Nenniger, 1948.

Fig. 26. Intranstylum barendrechti $\mathrm{n}$. sp.

Fig. 27. Pseudocarchesium amstelodamensis n. sp.

Fig. 28. Pseudocarchesium amstelodamensis n. sp., detail of branching. 

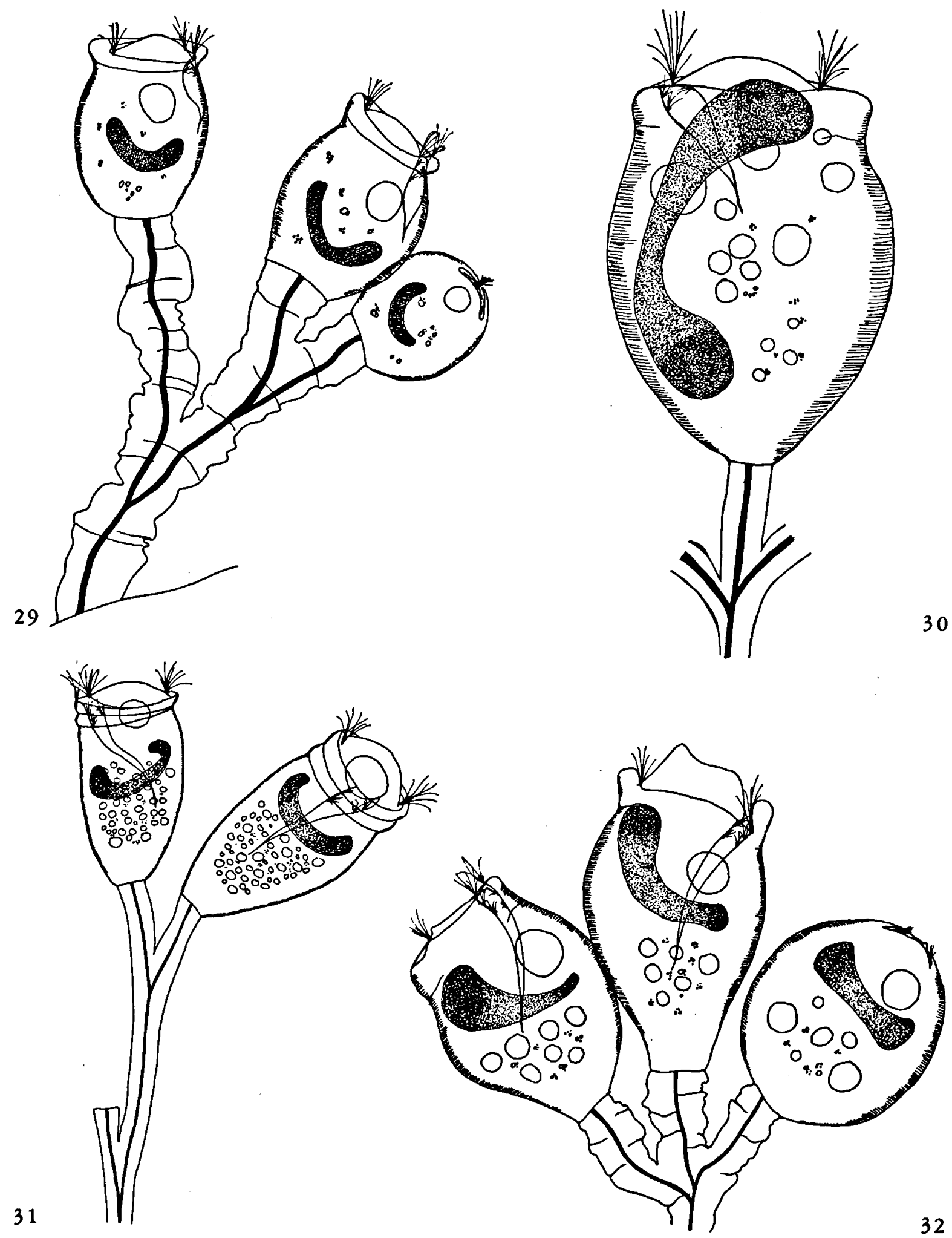

Fig. 29. Zoothamnium parasiticum Stein, 1859.

Fig. 30. Zoothamnium varians Stiller, 1933.

Fig. 31. Zoothamnium sp. a.

Fig. 32. Zoothamnium oviforme Sommer, 1951. 
Material: Waterland, 14.XI.1972, 20.XII.1972 and 17.V.1973, on G. tigrinus; Naardermeer, 18.IV.1973, on G. tigrinus.

Zooids $40 \times 60 \mu \mathrm{m}$.

Stalk thin and short.

Many colonies of different numbers of zooids.

Attachment: between the spines on the telson.

\section{Zoothamnium sp. a}

(Fig. 31)

Material: Waterland, 14.XI.1973, on G. tigrinus.

The zooid is vase-shaped. The peristome is more or less double. The discus is convex and slightly wrinkled. The contractile vacuole is situated at the level of the peristome, in the discus. The rather narrow vestibulum continues to about two-thirds of the length of the zooid. The Cshaped macronucleus is horizontally placed somewhat above the middle of the zooid. Many small food vacuoles are present in the lower part of the zooid. The pellicle shows a very fine transverse striation. The stalk is long and thin, the myoneme seems to be interrupted at several places.

Zooids $45 \times 80 \mu \mathrm{m}$.

Four colonies of more than 100 zooids.

Attachment: on coxal plates.

Zoothamnium oviforme Sommer, 1951

(Fig. 32)

Zoothamnium oviforme; Biegel, 1954: 169.

Material: Waterland, 30.XI.1972, on G. tigrinus.

Zooids $30 \times 45 \mu \mathrm{m}$.

One colony of many zooids.

Attachment: on the rim of the coxal plate of the first pereiopod.

Zoothamnium simplex Kent, 1881

(Fig. 33)

Zoothamnium simplex; Stiller, 1971: 188.

Material: Naardermeer, 19.1.1973, on G. tigrinus; Burgerbrug, 22.III.1973, on G. tigrinus.

Zooids $40 \times 85 \mu \mathrm{m}$.

Two colonies of 6 and 7 zooids.

Attachment: on the mouthparts.
Zoothamnium dudekemi Kahl, 1935

(Fig. 34)

Zoothamnium dudekemi Kahl, 1935: 743.

Material: Hierden, 22.II.1973 and 15.V.1973, on G. pulex.

Zooids $30 \times 60 \mu \mathrm{m}$.

Many colonies of $8-30$ zooids.

Attachment: on the pereiopods.

\section{Zoothamnium rigidum Precht, 1935}

(Fig. 35)

Zoothamnium rigidum Precht, 1935: 447.

Material: Hierden, 29.IX.1972, 22.II.1973, 15.V.1973 and 6.VIII.1973, on G. pulex.

Zooids $40 \times 75 \mu \mathrm{m}$.

Colonies up to $1.3 \mathrm{~mm}$, with more than 100 zooids.

Attachment: on the pereiopods.

\section{Zoothamnium sp. b}

(Fig. 36)

Material: Hierden, 22.II.1973, on G. pulex.

The zooid is vase-shaped, slightly narrowed at the base. The sausage-shaped peristome is somewhat inclined. The umbilicate discus is slightly wrinkled. The contractile vacuole lies high in the discus. The rather wide vestibulum continues into the lower half of the zooid. The sausageshaped, slightly bent macronucleus is situated nearly vertically near the middle of the zooid. Some large food vacuoles are present.

Zooids $40 \times 65 \mu \mathrm{m}$.

Some small colonies of $2-4$ zooids.

Attachment: on the pereiopods.

Zoothamnium kahlii Stiller, 1935, var. balatonicum Stiller, 1935

(Fig. 37)

Zoothamnium kahlii var. balatonicum; Stiller, 1971: 190.

Material: Hierden, 22.II.1973 and 26.IV.1973, on G. pulex.

Zooids $50 \times 100 \mu \mathrm{m}$.

Length of the colony up to $0.75 \mathrm{~mm}$.

Nine colonies of about 25 zooids.

Attachment: on the back. 

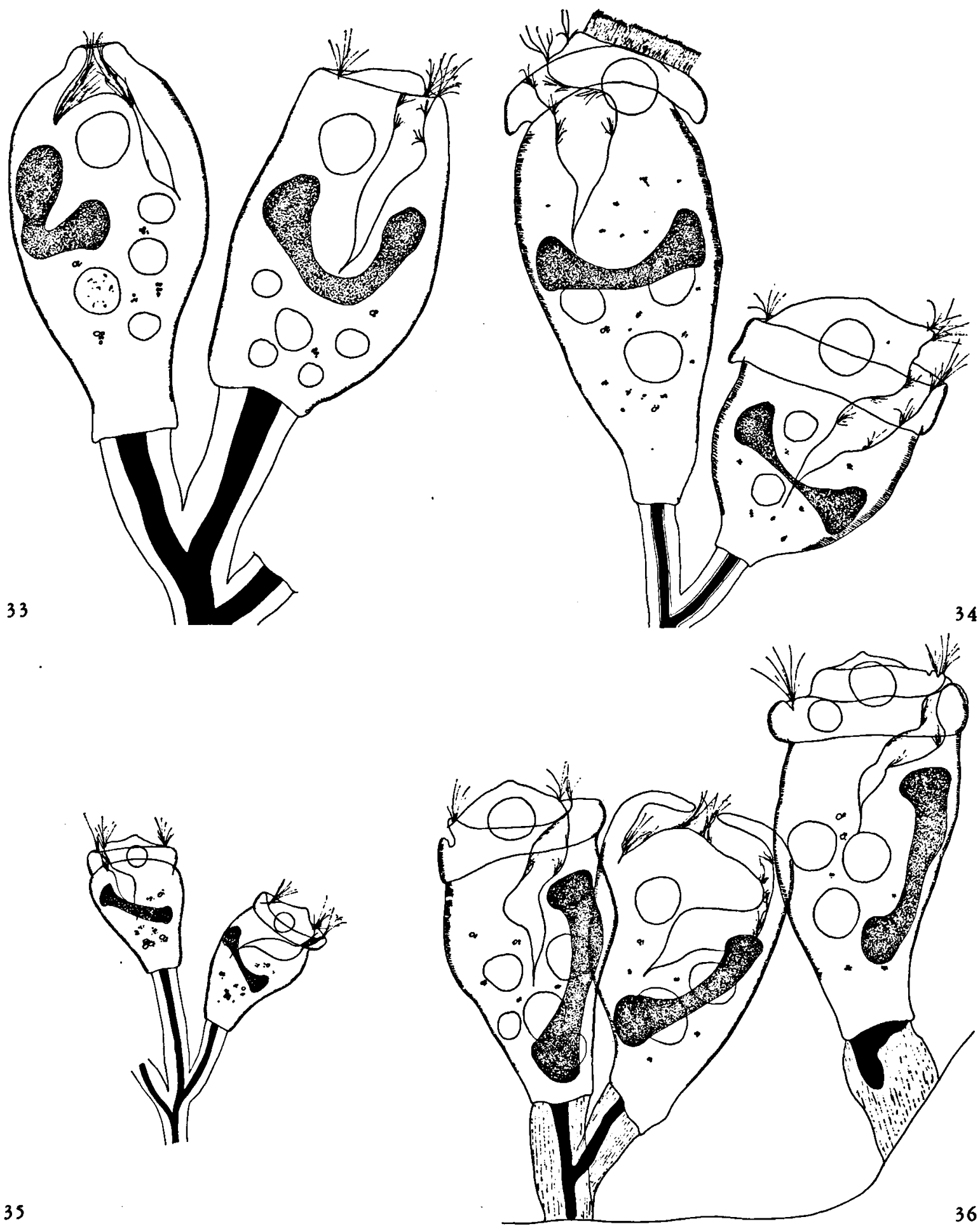

Fig. 33. Zoothamnium simplex Kent, 1881.

Fig. 34. Zoothamnium dudekemi Kahl. 1935.

Fig. 35. Zoothamnium rigidum Precht, 1935.

Fig. 36. Zoothamnium sp. b. 

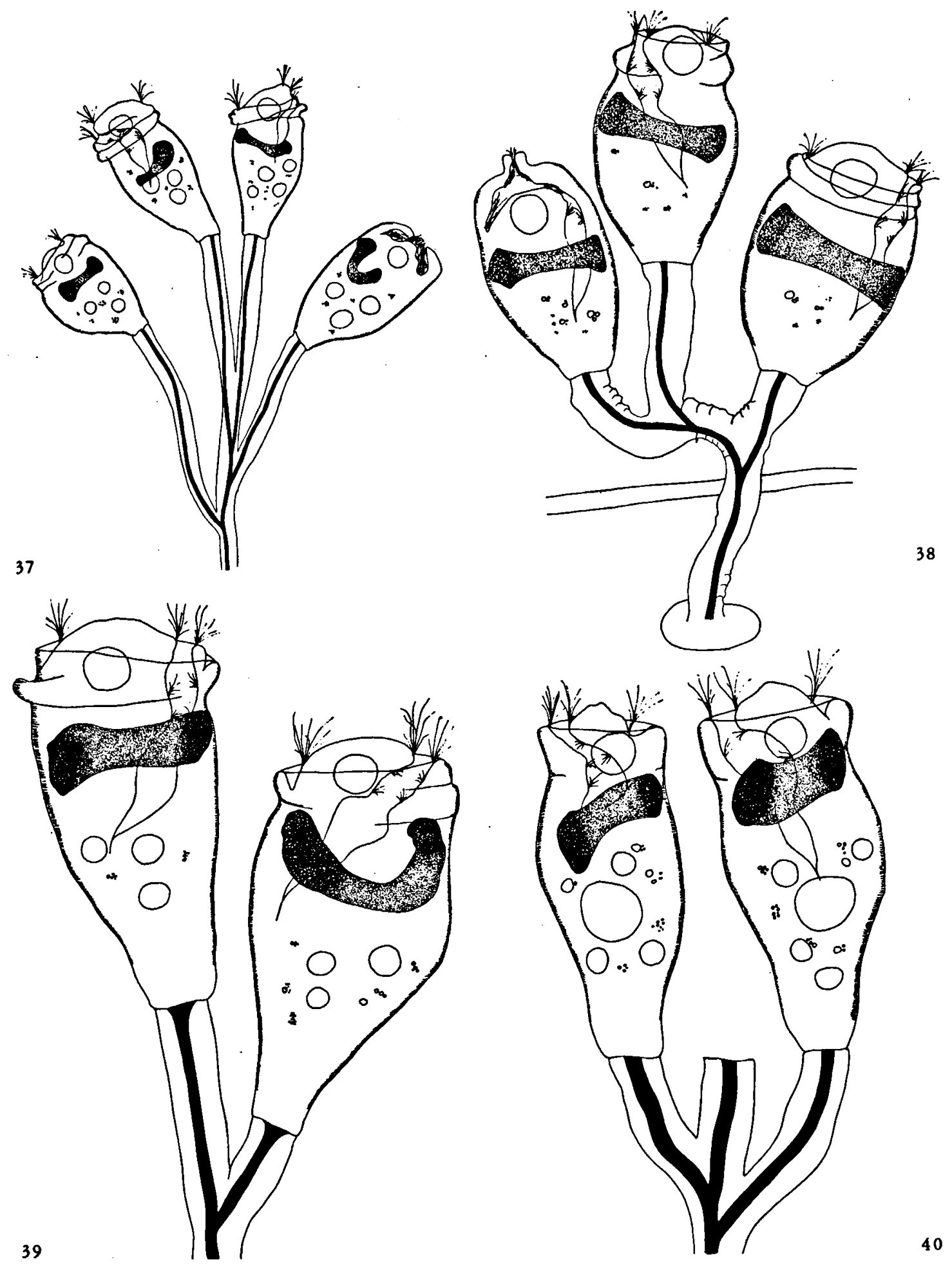

Fig. 37. Zoothamnium kahlii Stiller, 1935,

var. balatonicum Stiller, 1935.

Fig. 38. Zoothamnium carinogammari Stiller, 1971

Fig. 39. Zoothamnium duplicatum Kahl, 1933.

Fig. 40. Zoothamnium mucedo Entz sen., 1884. 
Zoothamnium carinogammari Stiller, 1971

(Fig. 38)

Zoothamnium carinogammari Stiller, 1971: 191.

Material: Waterland, 7.III.1973, on G. tigrinus.

Zooids $40 \times 65 \mu \mathrm{m}$.

Length of the colony up to $150 \mu \mathrm{m}$.

Three colonies of 3,12 and 35 zooids.

Attachment: on the coxal plates.

Zoothamnium duplicatum Kahl, 1933

(Fig. 39)

Zoothamnium duplicatum; Precht, 1935: 444.

Material: Hierden, 26.IV.1973, on G. pulex.

Zooids $45 \times 85 \mu \mathrm{m}$.

Many great colonies of $100-400$ zooids.

Attachment: on gnathopods, pereiopods, epimeres and back.

Zoothamnium mucedo Entz sen., 1884

(Fig. 40)

Zoothamnium mucedo; Kahl, 1935: 749.

Material: Diemen, 10.IV.1973, on G. tigrinus; Bullewijk, 19.VI.1973, on G. tigrinus.

Zooids $35 \times 85 \mu \mathrm{m}$.

Two colonies of 4 and 11 zooids.

Attachment: on the mouthparts.

Zoothamnium affine Stein, 1859

(Fig. 41)

Zoothamnium affine; Stiller, 1971: 178.

Material: Gein, 23.VII.1973, on G. tigrinus.

Zooids $25 \times 60 \mu \mathrm{m}$.

Three colonies of 8 and 9 zooids.

Attachment: on the first maxilla.

Zoothamnium ramosissimum Sommer, 1951

(Fig. 42)

Zoothamnium ramosissimum Sommer, 1951: 399.

Material: Hierden, 14.XII.1972, 22.II.1973, 26.IV.1973, T5.V.1973 and 6.VIII.1973, on G. pulex.

Zooids $45 \times 80 \mu \mathrm{m}$.

Length of the colony $250 \mu \mathrm{m}$.
Several colonies of $2-15$ zooids.

Attachment: on back and coxal plates.

Zoothamnium minimum Stiller, 1935, var. major Stiller, 1935

(Fig. 43)

Zoothamnium minimum var. major; Stiller, 1971: 182.

Material: Bullewijk, 19.VI.1973, on G. tigrinus.

Zooids $25 \times 40 \mu \mathrm{m}$.

Stalk $15 \times 50 \mu \mathrm{m}$.

Eight colonies of 2, 3, 4 and 5 zooids.

Attachment: on the rim of the gills.

Zoothamnium hyalinum Stiller, 1971

(Fig. 44)

Zoothamnium hyalinum Stiller, 1971: 183.

Material: Hierden, 6.VIII.1973, on G. pulex.

Zooids $35 \times 60 \mu \mathrm{m}$.

Stalk $15 \times 75 \mu \mathrm{m}$.

Three colonies of 3,4 and 5 zooids.

Attachment: on the pleopods.

\section{Order SUCTORIDA}

Family ACINETIDAE

Acineta foetida Maupas, 1881

(Fig. 45)

Acineta foetida; Kahl, 1934: 209.

Material: Hierden, 26.IV. 1973, on G. pulex.

Zooid $35 \times 40 \mu \mathrm{m}$.

Length of the stalk $35 \mu \mathrm{m}$.

One specimen.

Attachment: between the spines on the telson.

\section{Acineta sp.}

(Fig. 46)

Material: Kromme Mijdrecht, 12.XII.1973, on G. tigrinus.

The zooid is oblong, tapering at the base. The contractile vacuole lies high in the zooid. The elliptical macronucleus is situated in the middle 


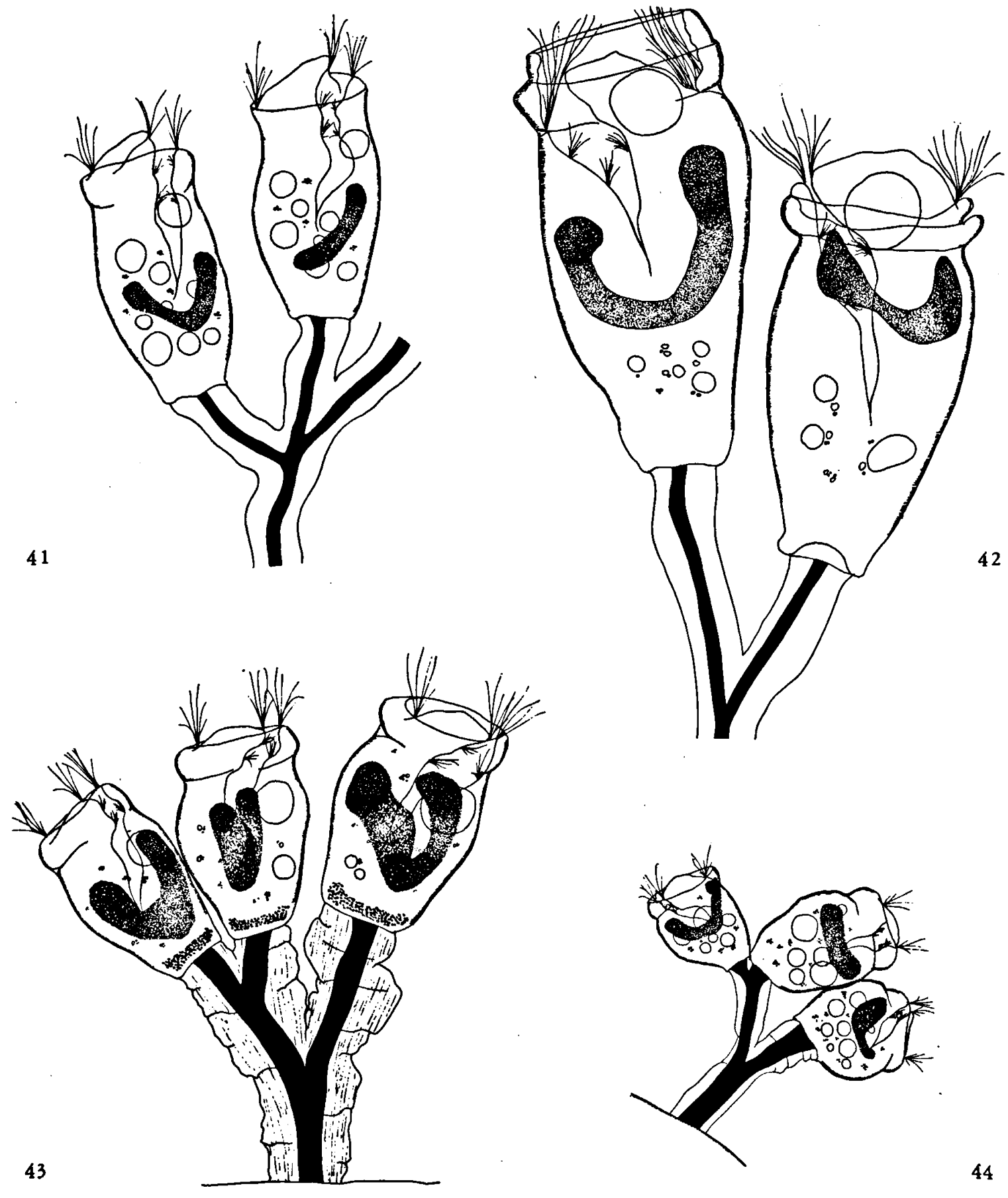

Fig. 41. Zoothamnium affine Stein, 1859.

Fig. 42. Zoothamnium ramosissimum Sommer, 1951.

Fig. 43. Zoothamnium minimum Stiller, 1935, var. major Stiller, 1935.

Fig. 44. Zoothamnium hyalinum Stiller, 1971. 

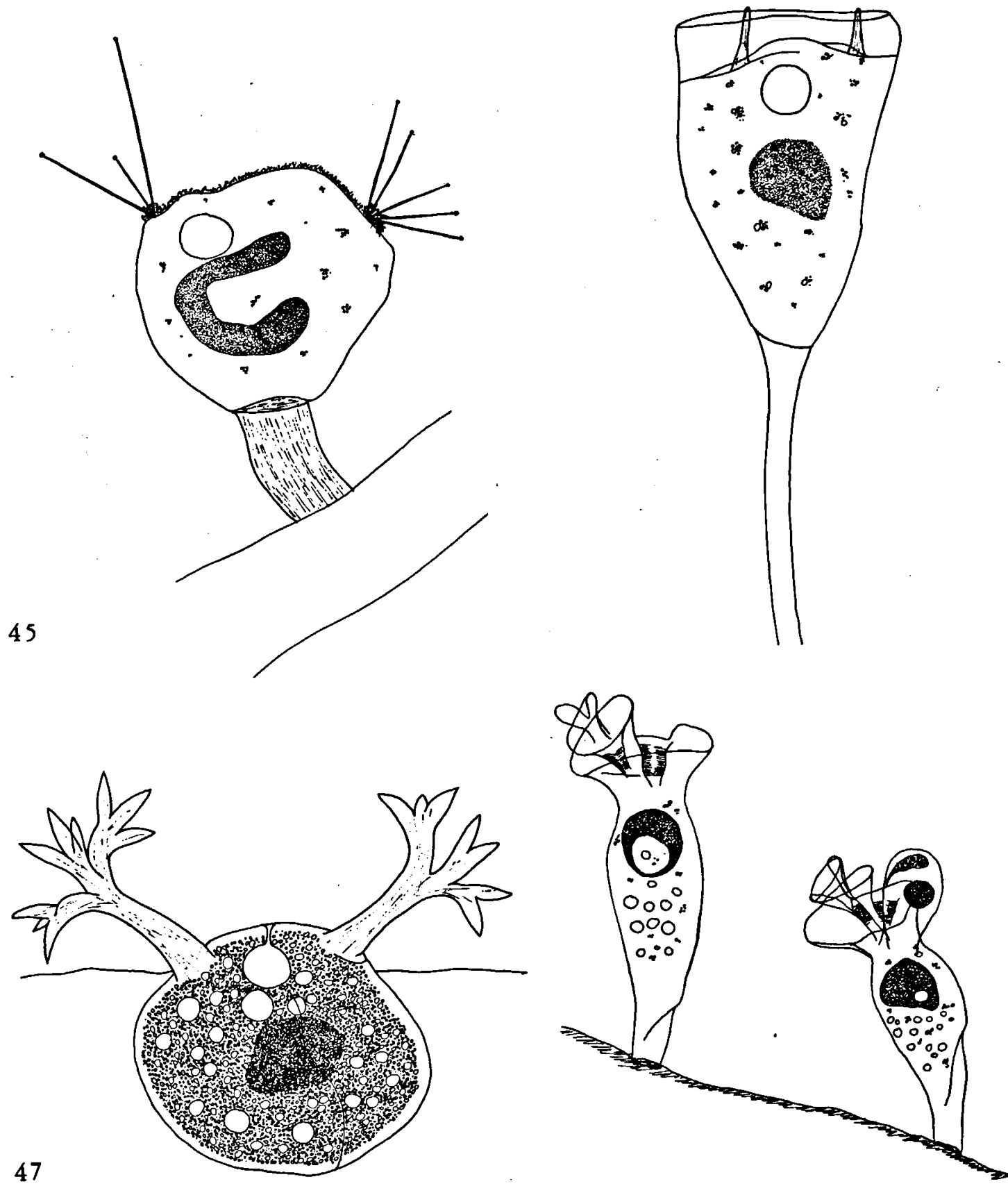

Fig. 45. Acineta foetida Maupas, 1881.

Fig. 46. Acineta sp.

Fig. 47. Dendrocometes paradoxus Stein, 1851.

Fig. 48. Spirochona gemmipara Stein, 1851, right specimen budding.

of the zooid. Many refractive granula are Family DENDROCOMETIDAE present. The stalk is rather long.

Zooid $25 \times 45 \mu \mathrm{m}$.

Length of the stalk $120 \mu \mathrm{m}$.

One specimen.

Dendrocometes paradoxus Stein, 1851

Attachment: on the back in front of the telson.

(Fig. 47)

Dendrocometes paradoxus; Doflein \& Reichenow, 1953: 1159. 
Material: Hierden, 26.IV.1973 and 15.V.1973, on G. pulex.

Body $60 \times 80 \mu \mathrm{m}$.

Animal with tentacles $130 \times 180 \mu \mathrm{m}$.

Per gill $1-10$ animals.

Attachment: on and near the rims of the gills.

\section{Order CHONOTRICHIDA}

\section{Family SPIROCHONIDAE}

\section{Spirochona gemmipara Stein, 1851}

(Fig. 48)

Spirochona gemmipara; Doflein \& Reichenow, 1953: 1154.

Material: Hierden, 26.IV.1973, 15.V.1973 and 6.VII.1973, on G. pulex.

Animals $30 \times 130 \mu \mathrm{m}$.

Per gill groups of $3-25$ animals.

Attachment: on the rims of the gills.

\section{Biological part}

\section{SEASONAL VARIATION}

During autumn there is an increase in number of epizoic ciliates. This is most probably related to dying and rotting of plant material. The subsequent rise of mineralizing bacteria increases the available food for the ciliates (see also Hamman, 1952). In winter the number of epibionts strongly declines, although they never disappear completely. On each Gammarus some small colonies or solitary ciliates were always to be found.

Spring shows a new increase in numbers. The colonies present grow in length as well as in number of zooids. During summer there is another decrease in the settlement of sedentary ciliates. In this respect our epizoic ciliates follow the general pattern as described for peritrichous ciliates.

The genus most commonly found on Gammarus is Zoothamnium. Nearly all Gammarus proved to bear at least some colonies of that genus. Especially in autumn those colonies reached considerable dimensions, visible to the naked eye.
Epistylis was likewise to be found during all seasons, although in smaller numbers, and mostly in smaller colonies.

Vorticella occurred in great numbers during spring and summer only. The other genera appear scattered and in small numbers during the whole year.

\section{DISTRIBUTION OF THE CILIATES OVER THE} BODY OF THE HOST

a. Zoothamnium settles everywhere on the body, including quickly moving parts like pereiopods and gnathopods. Only large colonies of more than 200 zooids are bound to the less moving parts on the outside body surface, as coxal plates, epimeres and the back.

b. Epistylis grows predominantly on these outside surfaces or on moving parts with a limited movement, like gills and mouthparts. On pereiopods Epistylis occurs only in small colonies, sheltered between spines or setae.

c. Vorticella is found on the "outer" parts of the body, like telson, pereiopods and antennae.

d. Carchesium, Haplocaulus, Intranstylum and Pseudocarchesium are found on more proximal parts like gills, base of legs, gnathopods, coxal plates and epimeres. They also occur on the telson.

e. Spirochona and Dendrocometes occur exclusively on the gills.

f. The very few Acinetidae were found near the telson.

There is slight evidence that the acontractile genus Epistylis prefers more quiet and sheltered localities on the host. The genera like Zoothamnium and Vorticella, with a contractile stalk, on the contrary, settle on more exposed and moving parts. This may be related to the possibility of the contractile genera of pulling aside, thus reacting to changes in their surroundings and avoiding collisions with sweeping body parts. The relative long stalk of Vorticella renders this genus unfit for small spaces. This genus occurs predominantly on the outside of the host. Most genera occur also on the telson.

The fact that all ciliate species, with the only exception of Haplocaulus distinguendis, occur on one of the Gammarus species, does not necessarily lead to the conclusion that all these ciliates are host-specific. Therefore the eco- 
logical properties of the waters from which the samples are taken, differ too much.

Under unfavorable circumstances zooids detach themselves from their stalks and escape. In Vorticella, Carchesium and Intranstylum mostly an aboral band of locomotory cilia was formed, giving rise to a true telotroch. In Epistylis and Zoothamnium the unchanged zooids detach themselves and swim about. This process leads to dismantling of colonies and change in species composition. This may occur especially during transport and storage in the laboratory. However, one sample of Gammarus, after having been investigated partially, was kept at $8^{\circ} \mathrm{C}$, without food supply or aeration for one month and a half. There appeared to be no significant change in species composition. Nevertheless, samples were always investigated as soon as possible after collection, within a few days.

\section{SUCCESSION OF CILIATE GENERA AFTER EC- DYSIS}

Exact data on the age of the exoskeleton of the host are wanting. We found clean, light coloured gammarids as well as darker ones, covered with detritus and often small filamentous algae. Supposedly the first ones moulted shortly before. On these, often small Epistylis colonies are found, while Zoothamnium is quite absent. On "older" animals, Zoothamnium starts growing in small colonies too, gradually supplanting Epistylis. On the apparently oldest exoskeletons only large
Zoothamnium colonies are present, while Epistylis is lacking. Probably this is due to food- and/or space competition. As the other genera were found in very small numbers, no succession could be demonstrated for them.

\section{LITERATURE}

Biegel, M., 1954. Beitrag zur Peritrichenfauna der Umgebung Erlangens. Arch. Protistenk., 100: 153-182.

Doflein, F. \& E. Reichenow, 1953. Lehrbuch der Protozoenkunde: i-viii, 1-1213 (Fischer, Jena).

Fenchel, T., 1965. On the ciliate fauna associated with the marine species of the amphipod genus Gammarus J. G. Fabricius. Ophelia, 2: 281-303.

Hamman, I., 1952. Oekologische und biologische Untersuchungen an Sūsswasserperitrichen. Arch. Hydrobiol., 47: $177-228$.

KAHL, A., 1934. Suctoria. Tierwelt N.- u. Ostsee, 26: 184-226.

-, 1935. Urtiere oder Protozoa. I: Wimpertiere oder Ciliata, 4. Peritricha und Chonotricha. Tierwelt Dtl., 30: $651-886$.

MatThes, D., 1950. Beitrag zur Peritrichenfauna der Umgebung Erlangens. Zool. Jb. (Syst.), 79: 437-448.

Nenniger, U., 1948. Die Peritrichen der Umgebung von Erlangen, mit besonderer Berücksichtigung ihrer Wirtsspezifität. Zool. Jb. (Syst.), 77: 169-265.

Precht, H., 1935. Epizoen der Kieler Bucht. Nova Acta Leopoldina, 3: $405-474$.

Sommer, G., 1951. Die Peritrichen des Grossen Plöner Sees. Arch. Hydrobiol., 44: 349-440.

STILLER, J., 1941. Einige Gewāsser der Umgebung von Szeged und ihre Peritrichenfauna. Arch. Hydrobiol., 36: $313-435$.

-, 1971. Szájkoszorús Csillósok-Peritricha. Fauna Hung., 105: 1-245. 